\title{
Corporate Governance, Financial Characteristics, Macroeconomic Factors and Financial Performance of Agricultural Firms Listed at the Nairobi Securities Exchange, Kenya
}

\author{
Dr. Moses Odhiambo Aluoch, PhD \\ Kenyatta University, Kenya
}

Doi:10.19044/esj.2021.v17n19p71

Submitted: 04 May 2021

Accepted: 24 June 2021

Published: 30 June 2021
Copyright 2021 Author(s)

Under Creative Commons BY-NC-ND

4.0 OPEN ACCESS

Cite As:

Odhiambo Aluoch M. (2021). Corporate Governance, Financial Characteristics, Macroeconomic Factors and Financial Performance of Agricultural Firms Listed at the Nairobi Securities Exchange, Kenya.

European Scientific Journal, ESJ, 17(19), 71. https://doi.org/10.19044/esj.2021.v17n19p71

\section{Abstract}

This study sought to examine the relationships between corporate governance, financial characteristics, macroeconomic factors and financial performance of agricultural firms listed at the Nairobi Securities Exchange, Kenya. The specific objectives were to establish the effect of corporate governance on financial performance; to determine the intervening effect of financial characteristics on corporate governance and financial performance; to establish the moderating effect of macroeconomic factors on corporate governance and financial performance of listed agricultural firms; and to establish the joint effect of corporate governance, financial characteristics, macroeconomic factors and financial performance of listed agricultural firms in Kenya. This study is anchored on agency theory, transaction cost theory; political theory and cash conversion cycle theory. The study used census approach and a target population of seven agricultural firms listed at the Nairobi Securities Exchange between 2002 and 2016 was incorporated. The study used panel data. Corporate governance, financial characteristics and financial performance data was extracted from annual reports of the individuals firms while macroeconomic factors data was extracted from Central Bank of Kenya and Kenya National Bureau of Statistics economic reports. The study employed longitudinal descriptive research design. 
Descriptive and panel data regression analysis were conducted. Corporate governance had significant effect on financial performance of listed agricultural firms in Kenya; the intervening effect of financial characteristics on the relationship between corporate governance and financial performance was not determined; the moderating effect of macroeconomic factors on the relationship between corporate governance and financial performance was confirmed; and the joint relationship between corporate governance, financial characteristics and macroeconomic factors on financial performance was established. The study recommended a review of corporate governance principles and directors to comply with corporate governance structure and practices to enhance financial performance of firms.

Keywords: Corporate Governance, Macroeconomic Factors, Financial Characteristics, Financial Performance, Listed Agricultural Firms

\section{Introduction}

Agriculture has been the pillar of Kenyan economy for many years, contributing to about 30 percent of Gross Domestic Product (GDP) and more than 80 percent of National Employment. The sector contributes more than 60 percent of total Kenyan exports and contributes more than 40 percent to the government revenues (PWC, 2019). However, financial performance of listed agricultural firms in Kenya has posted different results over the period of the study due to various factors such as corporate governance, financial management, macroeconomic factors, weather patterns, agricultural activities, general political environment, oil prices and global a pandemic among others. The association between corporate governance and performance of agricultural firms has attracted several studies all over the world with different results (Roudaki, 2018; Zhan, 2021). Listed agricultural firms' committed to good corporate governance normally post good financial performance, and this is subject to favourable financial characteristics and macroeconomic factors (CMA, 2015). Major financial management variables normally intervene in the association between corporate governance and financial performance of listed agricultural firms. Financial management variables (financial characteristics) when judiciously managed should positively influence on the relationship between corporate governance and performance of listed agricultural firms (Aluoch, Iraya, Kaijage \& Ogutu, 2020). Macroeconomic factors affect macroeconomic environment and determine the level of performance of listed agricultural firms due to cost of capital benefits arising from favorable interest rates, inflation rates and exchange rates prevailing in the country (Hopt, 2021).

The above conceptualization on the relationships between corporate governance, financial characteristics, macroeconomic factors and financial 
performance of listed agricultural firms is explained by Agency theory by Jensen and Meckling (1976); Transaction cost theory by Coase (1973); Political theory by Pound (1992); and Cash conversion cycle theory by Richards and Laughlin (1980). The Agency theory is an arrangement between principals and agents in a firm. It is based on different relationships between shareholders and various agents. These agents perform various activities on behalf of shareholders (Jensen \& Meckling, 1976). Transaction cost theory examines how directors enter into agreements for their sources of goods and services as this reduces uncertainty as they have everything they need for the foreseeable future (Coase, 1973), Political theory brings the approach of developing voting support from shareholders, rather than by purchasing voting power. Hence having a political influence may direct corporate governance positively within an organization (Pound, 1992). Cash conversion cycle theory represents the interaction between the components of working capital and the flow of cash within a company and can be used to determine the amount of cash needed for any sales level (Richards \& Laughlin, 1980).

Corporate Governance is the process of governing the corporate, creation of corporate policies while keeping the vision and mission in mind, as well as catering to the interests of all the stakeholders including: shareholders, employees, government, suppliers, customers, creditors, management, and environment, among others. Corporate Governance, in its simplest form means, a set of laws, rules and regulations to govern the functioning and growth of a business (Agarwal, 2021). Corporate governance refers to 'the system by which companies are directed and controlled'. This direction and control can come from inside or outside the organisation. Internal corporate governance refers to government and control by the organs of the corporations. External corporate governance can be understood as the disciplinary effects exercised in a particular way by the takeover market on the directors but also, to a certain degree, effects exercised by the markets for directors, products and services (Hopt, 2021). Corporate governance policies and practices used in this study are: board composition which comprises both executive and non-executive directors, gender and ethnicity, board skills, experience and occupational expertise, board age, board size, board tenure, board tools, board ownership, board meetings and board compensation.

Injecting colossal sums of money to firms without training them on acceptable financial management practices is pitiable. Firms that access funds often collapse due to unacceptable financial management practices. Financial management functions are: investment function, financing function, dividend function and liquidity function which have direct influence to firm performance (Mwosi, Mutesigensi \& Ebong, 2018). Investment function involves efficient allocation of funds on viable ventures to generate wealth for 
a firm. It is the acquisition of capital assets to generate future cash flows to a firm and taking short term contingent opportunities in the financial market to generate more wealth. Financing function is the acquisition of funds for investment and operation activities. It deals with financial leverage that is proposition debt and equity in the capital structure of a firm. Dividend function deals with dividend policy that is the pattern of divined payments of a firm for a given period of time. Liquidity function is the ability of the firm to use current assets to pay current obligations (Brigham \& Davis, 2018).

Economic factors affect the performance of firms. Microeconomic factors exist within the company and are under the control of management; they include product, organizational culture, leadership, manufacturing or operations (quality), demand and factors of production. Macroeconomic factors exist outside the firms and are not under the control of management; they include social, environmental, political conditions, suppliers, competitors, government regulations and policies. Key macroeconomic factors include the Consumer Price Index (CPI), unemployment, gross domestic product (GDP), stock market index, corporate tax rate and interest rates. Macroeconomic factors can pose a positive or negative threat to the performance of a firm and are beyond the control of management (Dioha, Mohammed \& Okpanach, 2018; Egbunike \& Okerekeoti, 2018). The macroeconomic factors for this study are Gross Domestic Product (GDP), interest rates and inflation rates.

Financial performance is multi-faceted, and the appropriate measure selected to assess financial performance depends on the type of organization to be evaluated, and the objectives to be achieved through that evaluation. Financial performance is a measure of overall well-being of a firm in terms of wealth creation over a given period of time. It measures how a firm can use investment in long and short term assets to create wealth. Measures of financial performance can further be achieved using either accounting or market metrics with different theoretical foundation. Each of the two metrics has specific predispositions. Financial performance measures can be established on book value or market value. In this study Return on Assets (ROA) and Tobin's Q were used as measures of firm performance. ROA is a main ratio of firm performance of profitability (Saseela, 2018; Egbunike \& Okerekeoti, 2018; Aluoch et al., 2020).

Nairobi Securities Exchange (NSE) was established in the year 1954 as the main stock market in Kenya, with deliberate intentions by brokers of shares traded in listed organizations within the confines of societies act. It rebranded its name from Nairobi Stock Exchange to Nairobi Securities Exchange to reflect its wider functions into a full service organization that aids in commercial exchanges, clearance and transfer of equities among other 
financial assets and traded instruments. NSE is the only securities market in Kenya having different platforms for the listing and multiple securities trading. The market has an obligation to guarantee effective trading in securities and derivatives and enhances economic development. The firms are grouped into twelve different sectors agricultural segment being one of them. The current code of corporate governance sets out 19 principles and specific recommendations on structure and processes which companies should adopt in making good corporate governance part of their business dealings and culture (CMA, 2015). The financial performance of listed agricultural firms has been diverse in terms of profitability and value since the introduction of corporate governance framework by Capital Markets Authority (CMA, 2002). This is further influenced by financial characteristics and macroeconomic factors (Aluoch et al., 2020).

\section{Problem Statement}

The relationship between corporate governance and financial performance of listed and non-listed agricultural firms is contradicting in most countries (Zheng ,2021; Oleh Pasko, Chen, \& Wang,2021; Tleubaye, Bobojonov,Gagalyuk,García Meca \& Glauben,2020; Roudaki, 2018). The same trend has been experienced in Kenya where listed agricultural firms have realized varied results since the introduction of corporate governance framework by Capital Markets Authority (CMA, 2002). The new code sets out 19 principles and specific recommendations on structure and processes which companies should adopt in making good corporate governance part of their business dealings and culture (Shikanga, Mukanzi and Musiega, 2018; Ngwenze \& Kariuki,2017; CMA, 2015).

There were 7 listed agricultural firms at the Nairobi Securities Exchange as at 31st December, 2016. The financial performance of listed agricultural firms has been different since the commencement of corporate governance policies and practices. Kakuzi Limited had increased operating profit from KES 232,799,000 in the year 2014 to KES 757,779,000 in the year 2016. Kapchorua Tea Company Limited had increased operating profit from KES 182,079,000 in the year 2014 to KES 336,007,000 in the year 2016. Eaagads Limited posted operating loss of $\operatorname{KES}(58,676,000)$ in the year 2014 to profit KES 9,691,000 in the year 2016. Limuru Tea Company Limited had a decreased in operating profit from KES 2,078,000 in the year 2014 to operating loss of KES $(26,731,000)$ in the year 2016. Rea Vipingo Plantations Limited delisted in the year 2016 had operating profits of KES 647,992,000 in the year 2013 to KES 2,117,386,000 in the year 2015. Sasini Limited posted operating profit of KES 61,793,000 in the year 2014 to KES 1,020,758,000 in the year 2016. Williamson Tea Kenya Limited posted operating profit of KES 
1,041,033,000 in the year 2014 to KES 940,445,000 in the year 2016 (NSE, 2017).

\section{Literature Review \\ Theoretical Review}

Agency theory was developed by Jensen and Meckling (1976). The theory is grounded on the separation of ownership and control as well as the relationship between principals and agents. It is based on short term gains where principals delegate decision making authority to their agents; who are to use resources given by the principals to enhance principals' benefits. Agents however, may commit moral hazard by substituting principals' interest with their own (Fama \& Jensen, 1983). The principals normally monitor the activities of agents to ensure that they act on the interest of the firms. Monitoring costs are normally expensive and adversely affect the principals' income (Agrwal \& Knoeber, 1996). Agency theory has been applied to todays' firms since shareholders have realized that firm performance depends crucially on having the right managers at the helm and incentivizing them properly (Anderson, Bustamante, Guibaud, \& Zervos, 2018). The theory however has been criticized on its narrow perspective and it ignores other stakeholders. Daily, Dalton and Canella (2003) argue that there are two features that influence the prominence of agency theory. First, the theory is conceptually simple theory that reduces the corporation to two participants of managers and shareholders. Second, the theory suggests that employees or managers in organizations can be self-interested. However employees and managers must constitute a good governance structure rather than just providing the needs of shareholders. Bhimani (2008) argues that the agent may be succumbed to self-interest, opportunistic behavior and falling short of congruence between the aspirations of the principal and the agent's pursuits. Todays' firms have adopted various compensation structures to motivate the managers hence avoiding agency costs and conflicts as a result of principalagency relationships.

Transaction Cost Theory (TCT) originated from Coarse (1937) premised on why companies exist and grow to be so large. The TCT was later theoretical described and exposed by Williamson (1996). The TCT attempts to view the firm as an organization comprising of people with different views and objectives. Transaction costs are incurred in spending time researching, negotiating and agreeing a transaction. The TCT examines how directors would rather enter into agreements for their sources of goods and services as this reduces uncertainty as they have everything they need for the foreseeable future. By doing this the time and expense of sourcing materials is avoided. The unit of analysis in TCT is the transaction and it occurs when dealing with internal and external parties. TCT and agency theory essentially deal with 
same issues and problems of corporate governance. Whereas agency theory focuses on an individual agent, the TCT focuses on individual transactions which can be quantifiable. The Agency theory looks at the tendency of directors to act in their own best interests, pursuing salary and status; Transaction cost theory considers that managers (or directors) may arrange transactions in an opportunistic way and shareholders are residual receivers, concern about safety of their investment.

Political theory has a very long foundation. However, political theory and corporate governance was initiated by (Pound, 1992). Political theory brings the approach of developing voting support from shareholders, rather than by purchasing voting power. Hence having a political influence in corporate governance may direct corporate governance within the organization. Public interest is much reserved as the government participates in corporate decision making, taking into consideration cultural challenges (Pound, 1993). The political model highlights the allocation of corporate power, profits and privileges are determined via the governments' favor. The political model of corporate governance can have an immense influence on governance developments. Over the last decades, the governments have been seen to have a strong political influence on firms. As a result, there is an entrance of politics into the governance structure or firms' mechanism (Hawley \& Williams, 1996).

Cash Conversion Cycle theory was developed by Richards and Laughlin (1980). It is a wider framework of analysis known as the working capital cycle. It represents the interaction between the components of working capital and the flow of cash within a company and can be used in determining the amount of cash needed for any sales level. Cash Conversion Cycle (CCC) is used as an all-inclusive measure of working capital as it shows the time lag between spending for the purchase of raw materials and the collection of sales of finished goods. It is determined by adding stock conversion period in trade debtor's collection period and subtracting trade creditor's deferral period (Padachi, 2006). The number of days trade debtors; stock and trade creditors are used in the operationalization of the management of trade creditors and stock (Sharma \& Kumar, 2011).

\section{Empirical Review}

Zheng (2021) examined empirical analysis of listed agricultural corporate governance structure and corporate performance in China, using a sample of a-share agricultural listed companies in Shanghai and Shenzhen stock markets from 2013-2018. The study used multiple regression model to verify the three aspects of corporate governance structure and found that the relationship between corporate performance and research results shows that the relationship between equity concentration, equity balance, executive 
compensation and corporate performance of agricultural listed companies in China is in a "U" shape, and the size of the board of directors is significantly positively correlated with corporate performance to some extent, while the correlation between other governance structural factors and firm performance is not significant. The study however used three variables of corporate governance and a short period of time. This study used for a long period time from the year 2002 to the year 2016 and incorporated many variables of corporate governance to determine the relationship between corporate governance and firm performance of listed agricultural firms in Kenya.

Oleh Pasko et al., (2021) studied the relationship between board characteristics and financial performance: Evidence from Chinese listed agricultural companies. The study investigated the data of Chinese agricultural listed companies from 2008 to 2017 , using multiple regression and found that CEO duality and board size are significantly positively correlated with financial performance as measured by ROA, ROE, and EPS and board independence had no significant impact on financial performance in China. The study's findings enrich the understanding of linkage "board structurefirm performance", especially in China. The study concentrated on board structure, this study however incorporates both board structure and board activities.

Tleubaye et al., (2020) examined corporate governance and firm performance within the Russian agri-food sector: does ownership structure matter? The study employed unique panel data obtained from 203 companies for the years between 2012 and 2017. A random effects model was used to analyse the impacts of ownership concentration and ownership identity on the firms' financial performance, measured by return on assets and return on sales. The results indicated an inverse U-shaped association between ownership concentration and firm performance, with average level of ownership concentration found to be on the descending range of the inverse U-shaped curve. The study also observed a similar quadratic relationship between ownership concentration by government and directors and firm performance. On average, ownership by directors was found to be on the ascending range and below the peak point, suggesting a potential for further performance improvement, while the impact of agro-holding ownership was found to be linear and positive. The study concentrated on ownership concentration, however this study include board structure and board activities of listed agricultural firms in Kenya.

Roudaki (2018) studied corporate governance structure and firm performance in large agricultural corporations in New Zealand. The study included external auditor remuneration and board characteristics such as board ownership, board compensation, board independence, board gender diversity in the context of agricultural companies by applying agency theory. The study 
used balanced panel data and generalized least squares regression analysis of 80 firms for a period of the year 2012 to year 2015 and found different results. External auditors' remuneration, board compensation, board independence has no association with agricultural companies' performance, while board gender diversity and board ownership were negatively but significantly associated with firm performance. The study used many corporate governance mechanisms to determine the relationship between corporate governance and performance of agricultural firms in New Zealand, however the study period was short, this study used for a long period time from the year 2002 to the year 2016 and incorporated intervening and moderating variables to determine overall effect on the relationship between corporate governance and firm performance of listed agricultural firms in Kenya.

Shikanga et al, (2018) examined influence of corporate governance on financial performance of listed agricultural firms in the Nairobi Securities Exchange, Kenya. The study used descriptive survey design, descriptive statistics and regression analysis. The study found that despite tight regulatory framework, corporate agricultural firms listed Kenya has experience decline in performance and some have been delisted. Financial and governance problems have made some firms to be put on statutory management. The study further established direct relationship between corporate governance and dimensions of financial performance as significant. The study however is not clear on the period of study, delisted firms and mechanisms of corporate governance. This study is for a period between the year 2002 to the year 2016, using specific mechanisms of corporate governance and Tobin's Q and ROA as measures of firm performance.

Ngwenze et al., (2017) studied effects of corporate governance practices on financial performance of listed agricultural firms in the Nairobi Securities Exchange, Kenya using corporate governance characteristics as board of directors' composition, board size, independence of board and board audit committees. The study used descriptive correlation research design to determine the relationship between corporate governance and financial performance of listed agricultural firms from the year 2012 to the year 2014. Data was analyzed using a regression model and the study established that corporate governance has no significance influence on performance as measured by Return on Equity (ROE) and Return on Assets (ROA), but has significance influence on capital structure. The study used a short period time and a few mechanisms of corporate governance to determine the relationship between corporate governance and financial performance of listed agricultural firms. This study however used along period from the year 2002 to the year 2016, used many corporate governance mechanisms and intervening and moderating variables to establish the relationship between corporate governance and financial performance of listed agricultural firms. 


\section{Research Methodology}

This study used a census approach given a few number of agricultural firms listed in Kenya and therefore a target population of 7 listed agricultural firms at the NSE between years 2002 and 2016 were used. These listed agricultural firms were targeted because they need to adhere to Kenya Capital Markets Authority (CMA) guidelines to corporate governance for continuous listing at the Nairobi Securities Exchange. The firms were screened against various factors which included availability of data for the period under review and the integrity of data. Data was extracted from annual reports of listed agricultural firms from CMA; published financial statements from NSE; and economic reports from Central Bank of Kenya (CBK) and Kenya National Bureau of Statistics (KNBS).

This study used descriptive and panel data regression in analyzing the relationships between corporate governance and financial performance of agricultural firms listed at the NSE. Descriptive analysis was carried out to measure central tendencies and dispersion of variables and coefficient of variation was used to disclose the volatility in relationships of the variables under study. A panel data regression analysis was conducted using random effects model which allowed the listed agricultural firms to have a common mean value of intercept and to determine whether corporate governance affect financial performance of agricultural firms. Coefficient of determination $\left(\mathrm{R}^{2}\right)$ and $\mathrm{p}$-values were used to interpret the regression functions at a level of significance of 0.05 (Bryman \& Cramer, 1997). The respective individual regression coefficients were also tested for their statistical significance using the t-test.

Direct relationship between Corporate Governance and Financial Performance of listed agricultural firms: simple regression model were used to test hypothesis one $\left(\mathrm{Ho}_{1}\right)$ : Relationship between Corporate Governance (CG) and Financial Firm Performance (FP).

$\mathrm{FP}_{\mathrm{it}}=\beta_{0}+\beta_{1} \mathrm{CG}_{\mathrm{it}}$ $+\dot{\varepsilon}_{\mathrm{it}}$ Equation 1.

The intervening effect of Financial Characteristics on the relationship between Corporate Governance and Financial Performance of listed agricultural firms: stepwise regression model was used to determine these relationships. The following models were used to test hypothesis two $\left(\mathrm{Ho}_{2}\right)$. This was achieved by determining the intermediating effect of firm characteristics by relying on four steps of statistical analysis (Baron \& Kenny, 1986). 
Step one: Relationship between Corporate Governance (CG) and Financial Performance of listed agricultural firms (FP) holding Firm Characteristics (FC) constant.

$\mathrm{FP}_{\mathrm{it}}=\beta_{0}+\beta_{1} \mathrm{CG}_{\mathrm{it}}+\dot{\varepsilon}_{\mathrm{it}}$ Equation2 (a).

Step two: Relationship between Corporate Governance (CG) and Financial Characteristics (FC), holding Performance of listed agricultural firms (FP) constant.

$\mathrm{FC}_{\mathrm{it}}=\beta_{0}+\beta_{2} \mathrm{CG}_{\mathrm{it}}+\dot{\varepsilon}_{\mathrm{it}}$ Equation2 (b).

Step three: Relationship between and Financial Characteristics (FC) and Financial Performance of listed agricultural firms (FP), holding Corporate Governance (CG) constant.

$\mathrm{FP}_{\mathrm{it}}=\beta_{0}+\beta_{3} \mathrm{FC}_{\mathrm{it}}+\varepsilon_{\mathrm{it}}$ Equation2 (c).

Step four: Intermediation among Corporate Governance (CG), Financial Characteristics (FC) and Financial Performance of listed agricultural firms (FP).

$\mathrm{FP}_{\mathrm{it}}=\beta_{0}+\beta_{4} \mathrm{CG}_{\mathrm{it}}+\beta_{5} \mathrm{FC}_{\mathrm{it}}+\dot{\varepsilon}_{\mathrm{it}}$ Equation2 (d).

Moderating effect of Macroeconomic Factors on the relationship between Corporate Governance and Financial Performance of listed agricultural firms: Multiple regression models were used to determine this relationship. The moderating model was used to test hypothesis three $\left(\mathrm{Ho}_{3}\right)$. This was achieved by determining the moderating effect of $\mathrm{FP}_{\text {it }}=\beta_{0}+\beta_{1} \mathrm{CG}_{\mathrm{it}}+\beta_{2} \mathrm{GDP}_{\mathrm{it}}+\beta_{3} \mathrm{INF}_{\mathrm{it}}+\beta_{4} \mathrm{INR}_{\mathrm{it}}+\beta_{5} \mathrm{GDP}_{\mathrm{it}} * \mathrm{CG}+\beta_{6} \mathrm{INF}_{\mathrm{it}} * \mathrm{CG}+$ $\beta_{7} \mathrm{INR}_{\mathrm{it}} * \mathrm{CG}+\stackrel{\varepsilon}{\varepsilon}_{\mathrm{it}}$ Equation 3.

Relationship among Corporate governance, Financial Characteristics, Macroeconomic Factors and Financial Performance of listed agricultural firms: Panel data regression model of random effects was used to determine the relationship among Corporate Governance (CG), Financial Characteristics (FC), Macroeconomic Factors (MF) and Financial Performance (FP). These models were used to test hypothesis four $\left(\mathrm{Ho}_{4}\right)$, the joint effect: $\mathrm{FP}_{\mathrm{it}}=\beta_{0}+\beta_{1} \mathrm{CG}_{\mathrm{it}}+\beta_{2} \mathrm{FC}_{\mathrm{it}-1}+\beta_{3} \mathrm{MF}_{\mathrm{it}-1}+\mathrm{c}_{\mathrm{i}}+\varepsilon_{\mathrm{it}} \ldots \ldots \ldots \ldots \ldots \ldots \ldots \ldots \ldots$ Equation 4. 
Where for all the relationships: $\mathrm{FP}_{\mathrm{ij}}$ is Financial Performance of listed agricultural firms; $\mathrm{CG}$ is Corporate Governance; $\mathrm{FC}$ is Financial Characteristics; MF is Macroeconomic Factors; $c_{i}$ unobserved variable; $\beta_{0}$ is the intercept; $\beta_{1}, \beta_{2}$, and $\beta_{3}$ are regression coefficients for Corporate Governance, Financial Characteristics and Macroeconomic Factors for firm i in time t; and is error term. The study's null hypotheses were rejected when calculated p-values exceeded 0.05 significance level adopted by the study (Aluoch ,Iraya, Kaijage \& Ogutu, 2019).

\section{Results And Discussions \\ Descriptive Statistics of Study Variables}

Table 1 shows the descriptive statistics of the variables under study. The results shows the mean standard deviation, minimum, maximum of corporate governance variables, financial characteristics variables, macroeconomic factors and financial performance variables of listed firms in agricultural firms in Kenya.

Table 1: Descriptive Statistics of Study Variables

\begin{tabular}{|c|c|c|c|c|c|}
\hline Variable & $\mathrm{N}$ & Mean & Standard Deviation. & Minimum & Maximum \\
\hline Board Independence & 104 & 0.66909 & 0.213475 & 0.25 & 1 \\
\hline Gender diversity & 104 & 0.011218 & 0.034625 & 0 & 0.125 \\
\hline Occupational Expertise & 104 & 3.903846 & 1.438171 & 1 & 6 \\
\hline Board Age & 104 & 56.69423 & 4.966346 & 46.5 & 69.7 \\
\hline Board Size & 104 & 5.586538 & 1.978577 & 2 & 9 \\
\hline Board Tenure & 104 & 3 & 0 & 3 & 3 \\
\hline Board Ownership & 104 & 0.005624 & 0.010501 & 0 & 0.0391 \\
\hline Board Tools & 104 & 2.605769 & 1.185825 & 0 & 4 \\
\hline Board Meeting & 104 & 3.346154 & 1.459946 & 0 & 6 \\
\hline Number of Board Committees & 104 & 1.692308 & 1.231283 & 0 & 3 \\
\hline Committees Meeting & 104 & 4.317308 & 3.388342 & 0 & 12 \\
\hline Board Remuneration & 102 & 0.031887 & -0.25781 & 1.272344 & 2.025853 \\
\hline Investments & 104 & 0.706689 & 0.163429 & 0.22458 & 0.992514 \\
\hline Leverage & 103 & 0.28088 & 0.199937 & 0.036099 & 1.041919 \\
\hline Liquidity & 103 & 0.187993 & 0.152948 & -0.1441 & 0.573307 \\
\hline GDP Growth Rate & 105 & 4.846667 & 2.190015 & 0.2 & 8.4 \\
\hline Interest Rate & 105 & 15.06825 & 2.258282 & 12.25 & 19.85333 \\
\hline Inflation Rate & 105 & 7.428 & 3.503312 & 0.9 & 15.2 \\
\hline ROA & 103 & 0.192208 & -0.2984 & 0.304929 & 1.797788 \\
\hline
\end{tabular}




\section{Correlation Analysis}

\section{Board Structure and Financial Characteristics in Listed Agricultural Firms}

Table 2 shows that board structure indicators had positive relationship with investments except board age which had $\mathrm{r}=0.07$ with firms investments implying there was very weak negative correlation between board age and investments in Agriculture firms listed on NSE. Occupational expertise $\mathrm{r}=0.331$ and board size $\mathrm{r}=0.315$ had a positive and strong correlation with investment compared to other indicators of board structures. The correlation between all the indicators of board structures and leverage was positive. Board independence, occupational expertise and board size had strong positive correlation with leverage compared to other indicators. Finally all the indicators of board structure were negatively correlated with liquidity of agricultural firms listed on NSE.

Table 2: Board Structure and Financial Characteristics Variables in Listed Agricultural

\begin{tabular}{|c|c|c|c|c|c|c|c|c|c|}
\hline \multicolumn{10}{|c|}{ Firms } \\
\hline & & $\begin{array}{l}\text { Board } \\
\text { Independence }\end{array}$ & $\begin{array}{l}\text { Gender } \\
\text { Diversity }\end{array}$ & $\begin{array}{l}\text { Occupational } \\
\text { Expertise }\end{array}$ & $\begin{array}{l}\text { Board } \\
\text { Age }\end{array}$ & $\begin{array}{l}\text { Board } \\
\text { Size }\end{array}$ & Investments & Leverage & Liquidity \\
\hline $\begin{array}{l}\text { Board } \\
\text { independence } \\
\text { Gender }\end{array}$ & $\mathrm{r}$ & 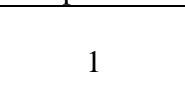 & & & & & & & \\
\hline $\begin{array}{l}\text { Diversity } \\
\text { Occupational }\end{array}$ & $\mathrm{r}$ & $.323 * *$ & 1 & & & & & & \\
\hline Expertise & $\mathrm{r}$ & $.459 * *$ & $.477 * *$ & 1 & & & & & \\
\hline Board Age & $\mathrm{r}$ & 0.009 & 0.036 & 0.137 & 1 & & & & \\
\hline Board Size & $\mathrm{r}$ & $.487 * *$ & $.494 * *$ & $.538 * *$ & 0.086 & 1 & & & \\
\hline Investments & $\mathrm{r}$ & 0.053 & $.244^{*}$ & $.331 * *$ & -0.07 & $.315^{* *}$ & 1 & & \\
\hline Leverage & $\mathrm{r}$ & $.234 *$ & 0.043 & $.250 *$ & 0.178 & $.273 * *$ & 0.086 & 1 & \\
\hline Liquidity & $\mathrm{r}$ & $-.266^{* * *}$ & -0.147 & $-.425 * *$ & 0.067 & $-.388^{* *}$ & $-.861 * *$ & $-.259 * *$ & 1 \\
\hline & $\mathrm{N}$ & 103 & 103 & 103 & 103 & 103 & 103 & 103 & 103 \\
\hline
\end{tabular}

\section{Board Activities and Financial Characteristics in Listed Agricultural Firms}

Table 3 presents the findings on correlation analysis between board activities indicators and financial characteristics (investments, leverage and liquidity). The findings showed that board tenure had a positive correlation with financial characteristics (investments, leverage and liquidity). Board ownership had negative correlation with investments and leverage while it had positive correlation with liquidity. The findings also showed that board tools was positively correlated with investments and negatively correlated with liquidity. Board meetings had a positive correlation with investments and leverage while it had negative correlation with liquidity. The findings further showed that number of board committees was positively correlated with 
investment and leverage while it had a negative correlation with liquidity. Board committee meetings on the other hand were positively correlated with investment and leverage and negatively correlate with liquidity. Board remuneration had a negative correlation with financial characteristics (investments, leverage and liquidity) of listed agricultural firms in Kenya.

Table 3: Board Activities and Financial Characteristics in Listed Agricultural Firms

\begin{tabular}{|c|c|c|c|c|c|c|c|c|c|c|c|}
\hline & & $\begin{array}{l}\text { Board } \\
\text { Tenure }\end{array}$ & $\begin{array}{c}\text { Board } \\
\text { Ownership }\end{array}$ & $\begin{array}{l}\text { Board } \\
\text { Tools }\end{array}$ & $\begin{array}{c}\text { Board } \\
\text { Meeti } \\
\text { ngs }\end{array}$ & $\begin{array}{c}\text { Board } \\
\text { Commit } \\
\text { tees }\end{array}$ & $\begin{array}{c}\text { Committe } \\
\text { es } \\
\text { Meetings }\end{array}$ & $\begin{array}{l}\text { Board } \\
\text { Remun } \\
\text { eration }\end{array}$ & $\begin{array}{l}\text { Invest } \\
\text { ments }\end{array}$ & $\begin{array}{l}\text { Leve } \\
\text { rage }\end{array}$ & $\begin{array}{l}\text { Liqu } \\
\text { idity }\end{array}$ \\
\hline $\begin{array}{l}\text { Board Tenure } \\
\text { Board }\end{array}$ & $\mathrm{r}$ & 1 & & & & & & & & & \\
\hline Ownership & $\mathrm{r}$ & -0.226 & 1 & & & & & & & & \\
\hline Board Tools & $\mathrm{r}$ & $.424 * *$ & $.197 *$ & 1 & & & & & & & \\
\hline $\begin{array}{l}\text { Board Meetings } \\
\text { Number of Board }\end{array}$ & $\mathrm{r}$ & 0.001 & 0.059 & $.365 * *$ & $\begin{array}{c}1 \\
.443 *\end{array}$ & & & & & & \\
\hline $\begin{array}{l}\text { Committees } \\
\text { Committees }\end{array}$ & $\mathrm{r}$ & 0.21 & $.524 * *$ & $.314 * *$ & $\begin{array}{c}* \\
.488 *\end{array}$ & 1 & & & & & \\
\hline $\begin{array}{l}\text { Meetings } \\
\text { Board }\end{array}$ & $\mathrm{r}$ & $-.367 * *$ & $.228^{*}$ & $.327 * *$ & $*$ & $.533 * *$ & 1 & & & & \\
\hline Remuneration & $\mathrm{r}$ & -0.014 & 0.133 & 0.014 & $\begin{array}{l}-0.022 \\
.643 *\end{array}$ & 0.07 & -0.008 & 1 & & & \\
\hline Investments & $\mathrm{r}$ & $.563 * *$ & $-.261 * *$ & $.482 * *$ & $*$ & 0.01 & 0.19 & -0.12 & 1 & & \\
\hline Leverage & $\mathrm{r}$ & $.349 *$ & -0.001 & $\begin{array}{c}.214^{*} \\
-\end{array}$ & 0.082 & $.342 * *$ & $.268 * *$ & -0.103 & $\begin{array}{c}0.086 \\
-\end{array}$ & $\begin{array}{l}1 \\
-\end{array}$ & \\
\hline Liquidity & $\begin{array}{l}\mathrm{r} \\
\mathrm{N}\end{array}$ & $\begin{array}{l}0.071 \\
-.349 *\end{array}$ & $\begin{array}{c}0.013 \\
103\end{array}$ & $\begin{array}{c}.589 * * \\
103\end{array}$ & $\begin{array}{l}-.661^{* *} \\
103\end{array}$ & $\begin{array}{l}-.292 * * \\
103\end{array}$ & $\begin{array}{l}-.309^{* *} \\
103\end{array}$ & $\begin{array}{c}-0.013 \\
101\end{array}$ & $\begin{array}{c}.361 * * \\
103\end{array}$ & $\begin{array}{l}.259 * * \\
103\end{array}$ & $\begin{array}{r}1 \\
103\end{array}$ \\
\hline
\end{tabular}

\section{Board Structure and Macroeconomic Variables in Listed Agricultural Firms}

Table 4 presents the results for board structure indicators and macroeconomic variables for listed firms in agricultural in Kenya. The findings presented showed that GDP growth rate had a negative correlation with board independence while it was positively correlated to gender diversity, occupation expertise, board age and board size. The findings further showed that interest was positively correlated with board structure indicators. Inflation had a positive correlation with board independence, gender diversity, occupational expertise and board age while it was negatively correlated board size. 
Table 4: Board Structure and Macroeconomic Variables in Listed Agricultural Firms

\begin{tabular}{|c|c|c|c|c|c|c|c|c|c|}
\hline & & $\begin{array}{l}\text { Board } \\
\text { Indepe } \\
\text { ndence }\end{array}$ & $\begin{array}{l}\text { Gender } \\
\text { Diversity }\end{array}$ & $\begin{array}{l}\text { Occupationa } \\
1 \text { Expertise }\end{array}$ & $\begin{array}{c}\text { Board } \\
\text { Age }\end{array}$ & $\begin{array}{l}\text { Board } \\
\text { Size }\end{array}$ & $\begin{array}{c}\text { GDP } \\
\text { Growth } \\
\text { Rate }\end{array}$ & $\begin{array}{l}\text { Interest } \\
\text { Rate }\end{array}$ & $\begin{array}{c}\text { Inflation } \\
\text { Rate }\end{array}$ \\
\hline \multicolumn{10}{|l|}{ Board } \\
\hline Independence & $\mathrm{r}$ & 1 & & & & & & & \\
\hline $\begin{array}{l}\text { Gender Diversity } \\
\text { Occupational }\end{array}$ & $\mathrm{r}$ & $.323 * *$ & 1 & & & & & & \\
\hline Expertise & $\mathrm{r}$ & $.759 * *$ & $.477 * *$ & 1 & & & & & \\
\hline Board Age & $\mathrm{r}$ & 0.009 & 0.036 & 0.137 & 1 & & & & \\
\hline Board Size & $\mathrm{r}$ & $.787 * *$ & $.494 * *$ & $.938 * *$ & 0.086 & 1 & & & \\
\hline GDP Growth Rate & $\mathrm{r}$ & -0.063 & 0.057 & 0.053 & $.341 * *$ & 0.02 & 1 & & \\
\hline Interest Rate & $\mathrm{r}$ & 0.002 & 0.069 & 0.061 & $.331 * *$ & 0.07 & -0.151 & 1 & \\
\hline Inflation Rate & $\mathrm{r}$ & 0.01 & 0.093 & 0.022 & $.227 *$ & -0.01 & $.262 * *$ & -0.126 & 1 \\
\hline
\end{tabular}

* Correlation is significant at the 0.05 level (2-tailed).

\section{Board Activities and Macroeconomic Variables in Listed Agricultural Firms}

Table 5 presents the findings of correlation analysis between board activities indicators and macroeconomic variables among agricultural firm listed on NSE. The findings showed that GDP growth rates, interest rates and inflation rates had weak relationship with board activities indicators for listed agricultural firms in Kenya.

Table 5: Board Activities and Macroeconomic Variables in Listed Agricultural Firms

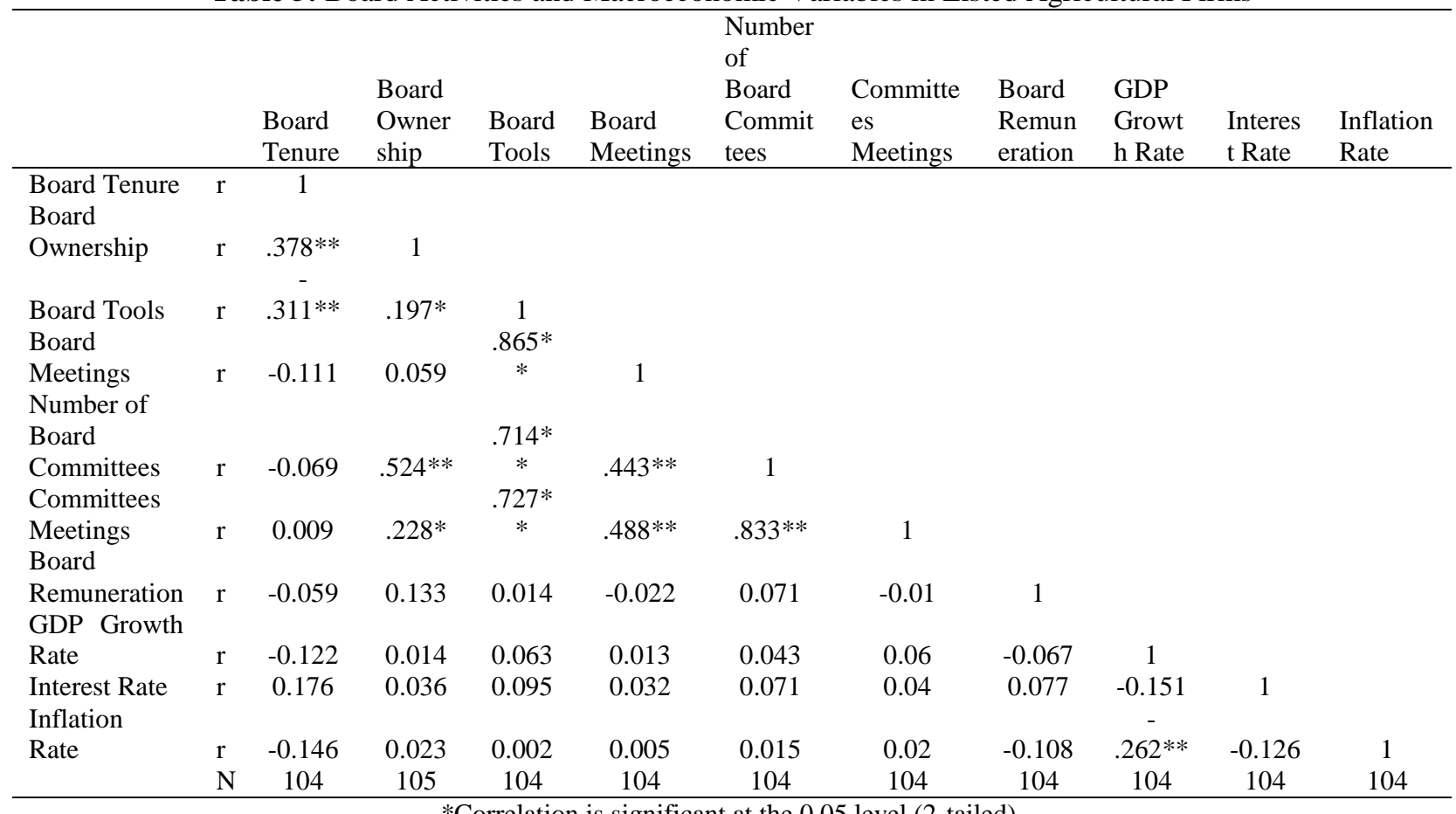

*Correlation is significant at the 0.05 level (2-tailed). 


\section{Board Structure and Financial Performance of Firms Variables in Listed Agricultural Firms}

Table 6 present the findings of correlation between board structures and financial performance of agricultural firms listed on NSE. The finding presented show that board structure variables had a weak association with ROA while had a strong correlation with Tobin's Q. The correlation between board independence, occupational expertise and board size and Tobin's Q was found to be very strong as shown by the finding in Table 6 .

Table 6: Board Structure and Financial Performance of Firms Variables in Listed

Agricultural Firms

\begin{tabular}{|c|c|c|c|c|c|c|c|c|}
\hline & & $\begin{array}{l}\text { Board } \\
\text { Independence }\end{array}$ & $\begin{array}{l}\text { Gender } \\
\text { Diversity }\end{array}$ & $\begin{array}{l}\text { Occupational } \\
\text { Expertise }\end{array}$ & $\begin{array}{l}\text { Board } \\
\text { Age }\end{array}$ & $\begin{array}{l}\text { Board } \\
\text { Size }\end{array}$ & ROA & Tobin's Q \\
\hline \multicolumn{9}{|l|}{ Board } \\
\hline Independence & $\mathrm{r}$ & 1 & & & & & & \\
\hline Gender Diversity & $\mathrm{r}$ & $.323 * *$ & 1 & & & & & \\
\hline \multicolumn{9}{|l|}{ Occupational } \\
\hline Expertise & $\mathrm{r}$ & $.559 * *$ & $.477 * *$ & 1 & & & & \\
\hline Board Age & $\mathrm{r}$ & 0.009 & 0.036 & 0.137 & 1 & & & \\
\hline Board Size & $\mathrm{r}$ & $.587 * *$ & $.494 * *$ & $.438 * *$ & 0.086 & 1 & & \\
\hline ROA & $\mathrm{r}$ & -0.01 & -0.078 & -0.067 & 0.143 & -0.121 & 1 & \\
\hline \multirow[t]{2}{*}{ Tobin’s Q } & $\mathrm{r}$ & $-.524 * *$ & -0.16 & $-.598 * *$ & $-.215^{*}$ & $-.595 * *$ & 0.14 & 1 \\
\hline & $\mathrm{N}$ & 103 & 103 & 103 & 103 & 103 & 103 & 103 \\
\hline
\end{tabular}

\section{Board Activities and Financial Performance of Firms in Listed Agricultural Firms}

Table 7 presents the findings of correlation analysis of board activities indicators and financial performance of agricultural firms listed in Kenya. The findings showed that board activities indicators had a weak correlation with ROA. However, the correlation between board activities' indicators and Tobin's Q was strongly. Board tools, board meetings, no board committees and committees meetings had strong negative correlation with Tobin's Q while board tenure had a positive correlation with Tobin's Q.

Table 7: Board Activities and Financial Performance of Firms in Listed Agricultural Firms

\begin{tabular}{|c|c|c|c|c|c|c|c|c|c|c|}
\hline & & $\begin{array}{l}\text { Board } \\
\text { Tenure }\end{array}$ & $\begin{array}{l}\text { Board } \\
\text { Owner } \\
\text { ship }\end{array}$ & $\begin{array}{l}\text { Board } \\
\text { Tools }\end{array}$ & $\begin{array}{l}\text { Board } \\
\text { Meeting } \\
\text { s }\end{array}$ & $\begin{array}{l}\text { Number } \\
\text { of Board } \\
\text { Committ } \\
\text { ees }\end{array}$ & $\begin{array}{l}\text { Committe } \\
\text { es } \\
\text { Meetings }\end{array}$ & $\begin{array}{l}\text { Board } \\
\text { Remune } \\
\text { ration }\end{array}$ & ROA & Tobin's Q \\
\hline $\begin{array}{l}\text { Board Tenure } \\
\text { Board }\end{array}$ & $\mathrm{r}$ & 1 & & & & & & & & \\
\hline Ownership & $\mathrm{r}$ & -0.111 & 1 & & & & & & & \\
\hline $\begin{array}{l}\text { Board Tools } \\
\text { Board }\end{array}$ & $\mathrm{r}$ & -0.069 & $.197 *$ & 1 & & & & & & \\
\hline $\begin{array}{l}\text { Meetings } \\
\text { Number of } \\
\text { Board }\end{array}$ & $\mathrm{r}$ & 0.009 & 0.059 & $.865 * *$ & 1 & & & & & \\
\hline $\begin{array}{l}\text { Committees } \\
\text { Committees }\end{array}$ & $\mathrm{r}$ & -0.059 & $.524 * *$ & $.714 * *$ & $.443 * *$ & 1 & & & & \\
\hline Meetings & $\mathrm{r}$ & 0.047 & $.228 *$ & $.727 * *$ & $.488 * *$ & $.833 * *$ & 1 & & & \\
\hline
\end{tabular}




\section{Board}

\begin{tabular}{lcccccccccc} 
Remuneration & $\mathrm{r}$ & 0.041 & 0.133 & 0.014 & -0.022 & 0.071 & -0.008 & 1 & \\
ROA & $\mathrm{r}$ & 0.034 & $.310^{* *}$ & -0.186 & $-.237^{*}$ & 0.062 & -0.074 & 0.04 & 1 & \\
& & & & & & & & & 0.14 & 1 \\
Tobin's Q & $\mathrm{r}$ & $.443^{* *}$ & -0.188 & $-.795^{* *}$ & $-.778^{* *}$ & $-.579 * *$ & $-.587 * *$ & -0.02 & 1 & 1 \\
& $\mathrm{~N}$ & 103 & 103 & 103 & 103 & 103 & 103 & 101 & 103 & 103 \\
\hline \multicolumn{8}{c}{ ** Correlation is significant at the 0.01 level (2-tailed). }
\end{tabular}

Financial Characteristics Variables and Financial Performance in Listed Agricultural Firms

Table 8 presents the findings of correlation analysis between financial characteristics and financial performance of agricultural firms listed at NSE. The findings showed that investments had a strong positive correlation with both ROA and Tobin's Q. Leverage had a weak correlation with both ROA and Tobin's $\mathrm{Q}$ while liquidity had strongly and positive correlation with Tobin's Q while weak correlation with ROA of listed Agricultural firms at NSE.

Table 8: Financial Characteristics Variables and Financial Performance in Listed

Agricultural Firms

\begin{tabular}{lcccccc}
\hline & & Investments & Leverage & Liquidity & ROA & Tobin's Q \\
\hline Investments & $\mathrm{r}$ & 1 & & & & \\
Leverage & $\mathrm{r}$ & 0.086 & 1 & & & \\
Liquidity & $\mathrm{r}$ & $-.861^{* *}$ & $-.259^{* *}$ & 1 & & \\
ROA & $\mathrm{r}$ & $.504 * *$ & 0.143 & $.447 * *$ & 1 & \\
Tobin's Q & $\mathrm{r}$ & $.567 * *$ & $.260^{* *}$ & $.615^{* *}$ & 0.141 & 1 \\
& $\mathrm{~N}$ & 103 & 103 & 103 & 103 & 103 \\
\hline \multicolumn{7}{c}{ Correlation is significant at the 0.05 level (2-tailed). }
\end{tabular}

\section{Macroeconomic Variables and Financial Performance Variables in Listed Agricultural Firms}

Table 9 presents the correlation analysis of macroeconomic variables and financial performance indicators of agricultural firms listed on NSE. The results presented showed that GDP growth rates, interest rates and inflation rates had a weak correlation with both ROA and Tobin's Q of listed agricultural firms in Kenya. 
Table 9: Macroeconomic Variables and Financial Performance Variables in Agricultural

\begin{tabular}{lcccccc}
\hline \multicolumn{7}{c}{ Firms } \\
& & $\begin{array}{c}\text { GDP Growth } \\
\text { Rate }\end{array}$ & $\begin{array}{c}\text { Interest } \\
\text { Rate }\end{array}$ & $\begin{array}{c}\text { Inflation } \\
\text { Rate }\end{array}$ & ROA & $\begin{array}{c}\text { Tobin's } \\
\text { Q }\end{array}$ \\
\hline GDP Growth Rate & $\mathrm{r}$ & 1 & & & & \\
Interest Rate & $\mathrm{r}$ & -0.151 & 1 & & & \\
Inflation Rate & $\mathrm{r}$ & $-.262^{* *}$ & -0.126 & 1 & & \\
ROA & $\mathrm{r}$ & 0.136 & 0.012 & 0.167 & 1 & \\
Tobin's Q & $\mathrm{r}$ & -0.027 & -0.086 & 0.059 & 0.141 & 1 \\
& $\mathrm{~N}$ & 103 & 103 & 103 & 103 & 103 \\
\hline & $* *$ Correlation is significant at the 0.05 level (2-tailed). & &
\end{tabular}

\section{Regression Analysis}

Hypothesis One (Ho1): Corporate Governance and Financial Performance of Listed Agricultural Firms

Table 10 shows both models used to link corporate governance variables to ROA (Prob $>$ Chi $2=0.0010)$ and Tobin's $\mathrm{Q}(\operatorname{Prob}>\mathrm{Chi} 2=0.0000)$ were statistically significant which implied that corporate governance variables were significant predictor of financial performance of listed agricultural firms in Kenya. The findings further revealed that only occupational expertise $(\beta=.1759128, p=0.043)$, board age $(\beta=.013589$, $\mathrm{p}=0.035)$, and board tools $(\beta=-.2199084, \mathrm{P}=0.014)$ significantly affected ROA of firms in agricultural sector. However board tools had a significant and negative effect on ROA, the rest of the corporate governance variables had an insignificant effect on ROA on listed agricultural firms in Kenya. On the other hand, only board tenure $(\beta=1.101152, p=0.000)$ and board meetings $(\beta=-$ $0.31549, \mathrm{p}=0.000)$ significantly affected the Tobin's $\mathrm{Q}$, the rest of the corporate governance variables had an insignificant effect on Tobin's Q on listed agricultural firms in Kenya. Table 11 presents the Random Effect (RE) regression results of the models fitted to test the relationship between CG composite and performance of firms (ROA and Tobin's Q) of listed agricultural firms in Kenya. The results revealed that the models fitted were statistically insignificant which implied that Corporate Governance (CG) composite was insignificant predictors of financial performance of firms (ROA and Tobin's Q) of listed agricultural firm in Kenya. 
Table 10: Corporate Governance Variables and Financial Performance of Listed Agricultural Firms

\begin{tabular}{|c|c|c|c|c|}
\hline & \multirow{2}{*}{$\begin{array}{l}\text { ROA } \\
\text { Coef. }\end{array}$} & \multicolumn{3}{|c|}{ Tobin's Q } \\
\hline & & $\mathrm{P}>|\mathrm{z}|$ & Coef. & $\mathrm{P}>|\mathrm{z}|$ \\
\hline Foreign Director & -.0014214 & 0.972 & 0.044167 & 0.658 \\
\hline Women Director & -.0764923 & 0.650 & 0.445122 & 0.284 \\
\hline Occupational Expertise & .1759128 & 0.043 & 0.190736 & 0.373 \\
\hline Board Age & .013589 & 0.035 & 0.007012 & 0.659 \\
\hline Board Size & -.0897128 & 0.213 & -0.23348 & 0.188 \\
\hline Board Tenure & -.1507205 & 0.225 & 1.101152 & 0.000 \\
\hline Board Ownership & 8.17801 & 0.057 & -8.74278 & 0.409 \\
\hline Board Tools & -.2199084 & 0.014 & -0.34776 & 0.115 \\
\hline Board Meetings & .0272355 & 0.566 & -0.31549 & 0.007 \\
\hline Number of Board Committees & .0100104 & 0.892 & -0.06929 & 0.704 \\
\hline Committees Meetings & .0254509 & 0.406 & 0.012576 & 0.868 \\
\hline Board Remuneration & .0365292 & 0.748 & 0.019105 & 0.946 \\
\hline \multirow[t]{4}{*}{ Cons } & \multicolumn{2}{|l|}{0.0000} & \multicolumn{2}{|l|}{0.0000} \\
\hline & \multicolumn{2}{|c|}{ Wald Chi2 $(11)=31.38$} & \multicolumn{2}{|c|}{ Wald Chi2 $(11)=205.06$} \\
\hline & \multicolumn{2}{|c|}{ Prob $>$ Chi $2=0.0010$} & \multicolumn{2}{|c|}{ Prob $>$ Chi $2=0.0000$} \\
\hline & \multicolumn{2}{|c|}{$\mathrm{R}-\mathrm{Sq}:=0.2607$} & \multicolumn{2}{|c|}{$\mathrm{R}-\mathrm{Sq}:=0.6973$} \\
\hline
\end{tabular}

Table 11: Model Corporate Governance Composite and Financial Performance of listed

\begin{tabular}{|c|c|c|c|c|}
\hline \multicolumn{5}{|c|}{ Agricultural Firms } \\
\hline & \multicolumn{2}{|l|}{ ROA } & \multicolumn{2}{|l|}{ Tobin's Q } \\
\hline & Coef. & $\mathrm{P}>|\mathrm{z}|$ & Coef. & $\mathrm{P}>|\mathrm{z}|$ \\
\hline & 0.00007 & & - & \\
\hline \multirow[t]{2}{*}{ CG } & 87 & 0.158 & 0.0000202 & 0.900 \\
\hline & 0.17242 & & & \\
\hline \multirow[t]{4}{*}{ cons } & 57 & 0.000 & 1.2159 & 0.003 \\
\hline & \multicolumn{2}{|c|}{ Wald chi $2(1)=2.00$} & \multicolumn{2}{|r|}{ Wald chi2 $2(1)=0.02$} \\
\hline & \multicolumn{2}{|c|}{ Prob $>$ chi $2=0.1577$} & \multicolumn{2}{|r|}{ Prob $>$ chi $2=0.9001$} \\
\hline & \multicolumn{2}{|c|}{$\mathrm{R}$-sq: $=0.0545$} & \multicolumn{2}{|r|}{ R-sq: $=0.0126$} \\
\hline
\end{tabular}

\section{Hypothesis Two (Ho2): Intervening Effect of Financial Characteristics on the Relationship between Corporate Governance and Financial Performance of Listed Agricultural Firms}

Intervention is deemed when corporate governance predicts financial performance of listed agricultural firms, corporate governance predicts financial characteristics and financial characteristics predicts financial 
performance of listed agricultural firms, additional corporate governance should predict financial performance of agricultural firms in presence of financial characteristics.

The first step of testing the intervening involves fitting a model for independent variables and dependent variables while ignoring the intervening variables. The study fitted a Random Effect (RE) effect model to test the relationship between CG composite and financial performance of listed agricultural firms' measures using ROA and Tobin's Q. Table 12 presents the $\mathrm{RE}$ regression results of the models fitted to test the relationship between $\mathrm{CG}$ composite and performance of firms (ROA and Tobin's Q). The regression coefficient further revealed an insignificant relationship between $\mathrm{CG}$ Composite and financial performance of firms $(\mathrm{ROA})(\beta=0.000, \mathrm{p}=0.1577)$ and Tobin's $Q(\beta=0.000, p=0.9001)$.

Table 12: Step One Random Effect Regression Results: Corporate Governance and Financial Performance

\begin{tabular}{lllll}
\hline & ROA & \multicolumn{3}{c}{ Tobin's Q } \\
\hline CG & Coef. & $\mathrm{P}>|\mathrm{z}|$ & Coef. & $\mathrm{P}>|\mathrm{z}|$ \\
_cons & 0.0000787 & 0.158 & -0.0000202 & 0.002 \\
& 0.1724257 & 0.000 & 1.2159 & 0.003 \\
& & & \\
& & & \\
& Wald chi2 $(1)=2.00$ & Wald chi2 $(1)=0.02$ \\
& Prob $>$ chi2 $=0.1577$ & Prob $>$ chi2 $=0.9001$ \\
& R-sq: $=0.0545$ & R-sq: $=0.0126$ \\
\hline
\end{tabular}

Step two involved testing the relationship between independent variable (corporate governance) and intervening variables (financial characteristics) as dependent variables. The results are presented in Table 13. The results revealed that first model that tested the relationship between CG and investments was statistically insignificant (Prob >chi2=0.6456). The second model fitted to test the relationship between $C G$ and leverage was statistically insignificant (Prob > chi2 $=0.7449$ ). The third model fitted to test the relationship between CG and liquidity was also statistically insignificant (Prob $>$ chi $2=0.5267)$. 
Table 13: Step Two Random Effect Regression Results: Corporate Governance and Financial Characteristics Variables

\begin{tabular}{lllllll}
\hline & \multicolumn{2}{l}{ Investments } & \multicolumn{3}{l}{ Leverage } & \multicolumn{2}{l}{ Liquidity } \\
\hline & Coef. & $\mathrm{P}>|\mathrm{z}|$ & Coef. & $\mathrm{P}>|\mathrm{z}|$ & Coef. & $\mathrm{P}>|\mathrm{z}|$ \\
\hline CG & 0.0000118 & 0.646 & -0.0000122 & 0.745 & -0.0000166 & 0.527 \\
Cons & 0.7041394 & 0.00 & 0.2753321 & 0.00 & 0.1897765 & 0.00 \\
& & & & & \\
& & & & \\
& Wald chi2(1)=0.21 & Wald chi2 $(1)=0.11$ & Wald chi2 $(1)=0.40$ \\
& Prob $>$ chi2 $=0.6456$ & Prob $>$ chi2 $=0.7449$ & Prob $>$ chi2 $=0.5267$ \\
& R-sq: $=0.0295$ & R-sq: $=0.0002$ & R-sq: $=0.0046$ \\
\hline
\end{tabular}

Step three in testing for the intervening involved regression effect of the intervening variables with dependent variables without the independent variables. The study also conducted diagnostics tests before fitting the models. The results presented in table 14 revealed that financial characteristics variables (investment, leverage and liquidity) had a significant effect on ROA and Tobin's Q. The two models fitted to link Financial Characteristics Variables to both ROA and Tobin's Q was statistically significant.

Table 14: Step Three RE Regression Results: Financial Characteristics Variables and Performance

\begin{tabular}{lllll}
\hline & ROA & \multicolumn{3}{l}{ Tobin's Q } \\
\hline & Coef. & $\mathrm{P}>|\mathrm{z}|$ & Coef. & $\mathrm{P}>|\mathrm{z}|$ \\
\hline Investments & -0.939179 & 0.004 & -3.326821 & 0.002 \\
Leverage & -0.1568998 & 0.258 & -0.6173152 & 0.096 \\
Liquidity & -0.0452337 & 0.899 & -1.378709 & 0.0215 \\
_cons & 0.9070948 & 0.003 & 3.989556 & 0.00 \\
& & & & \\
& Wald chi2(3)=35.51 & Wald chi2(3) $=19.77$ \\
& Prob $>$ chi2 $=0.0000$ & Prob $>$ chi2 $=0.0002$ \\
& R-sq: $=0.264$ & R-sq: $=0.2844$ \\
\hline
\end{tabular}

Step four in testing for intervening effects of financial characteristics involved fitting model to link independent variables and dependent variables in presence of intervening variables. 
Table 15: Step Four RE Regression Results: Corporate Governance, Financial Characteristics Variables and Financial Performance

\begin{tabular}{lllll}
\hline & ROA & \multicolumn{3}{l}{ Tobin's Q } \\
\hline & Coef. & $\mathrm{P}>|\mathrm{z}|$ & Coef. & $\mathrm{P}>|\mathrm{z}|$ \\
\hline CG & 0.0000781 & 0.097 & 0.0000898 & 0.558 \\
investments & 0.6815775 & 0.065 & 3.428609 & 0.002 \\
leverage & 0.1553226 & 0.326 & 0.7722257 & 0.072 \\
liquidity & 0.2227522 & 0.584 & 1.464623 & 0.211 \\
_cons & 0.6550839 & 0.064 & 4.139829 & 0.00 \\
& & & & \\
& Wald chi2(4) $=35.47$ & Wald chi2(4) $=21.06$ \\
& Prob $>$ chi2 $=0.0000$ & Prob $>$ chi2 $=0.0003$ \\
& R-sq: $=0.2901$ & R-sq: $=0.3213$ \\
\hline
\end{tabular}

\section{Summary Intervening Effect of Financial Characteristics in Listed Agricultural Firms}

The summary in table 16 shows that all the four steps for testing the intervening effects of financial characteristics on the relationship between corporate governance and financial performance of firms of listed agricultural firm in Kenya were not achieved the study concluded that intervention of financial characteristics was not fully achieved. Therefore the study failed to reject the null hypothesis that $\mathrm{H}_{02}$ - Financial characteristics do not significantly intervene in the relationship between corporate governance and financial performance of agricultural firms listed at the Nairobi Securities Exchange.

Table 16: Summary of the Intervening Effect of Financial Characteristics in Listed Agricultural Firms

\begin{tabular}{cllll}
\hline Steps & Independent Variable & Dependent Variable & Result & Intervention \\
\hline 1 & CG & ROA & Insignificant & Not Achieved \\
& & Tobin's Q & Insignificant & Not Achieved \\
\hline 2 & CG & Investment & insignificant & Not Achieved \\
& & Leverage & insignificant & Not Achieved \\
& & Liquidity & insignificant & Not Achieved \\
\hline \multirow{2}{*}{3} & Investment & ROA & significant & Achieved \\
& & Tobin's Q & significant & Achieved \\
& Leverage & ROA & insignificant & Not Achieved \\
& & Tobin's Q & insignificant & Not Achieved \\
& Liquidity & ROA & insignificant & Not Achieved \\
& & Tobin's Q & significant & Achieved \\
\hline \multirow{2}{*}{4} & CG & ROA & Insignificant & Not Achieved \\
& & Tobin's Q & Insignificant & Not Achieved \\
& Investment & ROA & insignificant & Not Achieved \\
& & Tobin's Q & significant & Achieved \\
& Leverage & ROA & insignificant & Not Achieved \\
& & Tobin's Q & insignificant & Not Achieved
\end{tabular}




\begin{tabular}{llll} 
Liquidity & ROA & insignificant & Not Achieved \\
& Tobin's Q & insignificant & Not Achieved \\
\hline
\end{tabular}

\section{Hypothesis Three (Ho3): Moderating effect of Macroeconomic Factors on the Relationship between Corporate Governance and Financial Performance of Listed Agricultural Firms in Listed Agricultural Firms}

This section presents for moderating effect of macroeconomic factors on the relationship between corporate governance variables and financial performance of agricultural firms listed on NSE in Kenya. Table 17 and Table 18 show that macroeconomic variables increased the explanatory power of corporate governance on financial performance of firms of listed agricultural firms in Kenya since the R-squared increased from 0.1165 and 0.1641 in the first model while increased from 0.0264 to 0.0345 in the second model. These results implied that macroeconomic variables positively enhanced the relationship between corporate governance and financial performance of listed agricultural firms in Kenya. The findings further implied that friendly macroeconomic variables enhance the effect of corporate governance on financial performance of listed agricultural firms in Kenya. Therefore the study rejected the null hypothesis that $\mathrm{H}_{03}$ : Macroeconomic factors do not significantly moderate the relationship between corporate governance and financial performance of agricultural firms listed at the Nairobi Securities Exchange. The first step of testing the intervening involves fitting a model for independent variables and dependent variables while ignoring the intervening variables, while the second step includes all intervening variables. The study fitted a Random Effect (RE) effect model to test the relationship between CG composite and financial performance of listed agricultural firms' as measured using ROA and Tobin's Q.

Table 17: Step One, Models Fitting for Moderating Effect of Macroeconomic Factors in Listed Agricultural Firms

\begin{tabular}{lllll}
\hline & \multicolumn{1}{c}{ ROA } & \multicolumn{2}{c}{ Tobin's Q } \\
\hline & Coef. & $\mathrm{P}>|\mathrm{z}|$ & Coef. & $\mathrm{P}>|\mathrm{z}|$ \\
\hline CG & 0.0000736 & 0.184 & 0.00000139 & 0.993 \\
GDP growth rate & 0.026699 & 0.044 & -0.0156382 & 0.615 \\
Interest rate & 0.0091354 & 0.462 & -0.0434667 & 0.136 \\
Inflation rate & 0.0201881 & 0.014 & 0.012657 & 0.51 \\
Cons & 0.243523 & 0.303 & 1.844694 & 0.015 \\
& & & & \\
& Wald chi2(4)=9.93 & Wald chi2(4) $=3.30$ \\
& Prob > chi2 $=0.0416$ & Prob $>$ chi2 $=0.5085$ \\
& R-sq: $=0.1165$ & R-sq: $=0.0264$ \\
\hline
\end{tabular}


Table 18: Step Two, Models Fitting for Moderating Effect of Macroeconomic Factors in Listed Agricultural Firms

\begin{tabular}{lclll}
\hline & ROA & \multicolumn{1}{c}{ Tobin's Q } \\
\hline Coef. & $\mathrm{P}>|\mathrm{z}|$ & Coef. & $\mathrm{P}>|\mathrm{z}|$ \\
GDP Growth Rate & -0.00079 & 0.134 & 0.0003276 & 0.88 \\
Interest Rate & 0.0260577 & 0.079 & -0.0191769 & 0.754 \\
Inflation Rate & 0.0009856 & 0.943 & -0.0296874 & 0.598 \\
IT1 & 0.0164138 & 0.074 & 0.0147889 & 0.696 \\
IT2 & 0.0000139 & 0.624 & 0.000028 & 0.810 \\
IT3 & 0.0000467 & 0.072 & -0.0000418 & 0.696 \\
Cons & 0.0000185 & 0.275 & -0.00000948 & 0.892 \\
& 0.1001064 & 0.697 & 1.705919 & 0.107 \\
& & & & \\
& Wald chi2(7) $=18.26$ & Wald chi2(7)= 2.52 \\
& Prob $>$ chi2 $=0.0109$ & Prob > chi2 $=0.9254$ \\
& R-sq:= & 0.1641 & R-sq: $=$ & 0.0345 \\
\hline
\end{tabular}

\section{Hypothesis Four (Ho4): Joint Effect of Corporate Governance, Financial Characteristics, and Macroeconomic Factors on Financial Performance of Listed Agricultural Firms}

The study analysed the effect of corporate governance, financial characteristics, and macroeconomic factors on financial performance of firms of listed agricultural firms in Kenya. At the point of the study NSE had a total of 7 agricultural firms listed therefore data for these 7 firms was used in this analysis. This section sought to test the hypothesis; $\mathrm{H}_{04}$-Corporate governance, financial characteristics and macroeconomic factors do not significantly jointly affect financial performance of agricultural firms listed at Nairobi Securities Exchange.

The results presented in Table 19 revealed that both model 1 linking Corporate Governance, Financial Characteristics, Macroeconomic Factors and ROA (Prob>chi2=0.0000), and Model 2 linking Corporate Governance, Financial Characteristics, Macroeconomic Factors and Tobin's Q (Prob $>$ chi2 $=0.0000$ ) were statistically significant. These findings implied that Corporate Governance, Financial Characteristics, Macroeconomic Factors were good predictors of financial performance of listed agricultural firms in Kenya. 
Table 19: Joint Effect of Corporate Governance, Financial Characteristics, Macroeconomic Factors on Financial Performance of Listed Agricultural Firms

\begin{tabular}{lllll}
\hline & \multicolumn{1}{c}{ ROA } & \multicolumn{3}{c}{ Tobin's Q } \\
\hline & Coef. & $\mathbf{P}>|\mathbf{z}|$ & Coef. & $\mathbf{P}>|\mathbf{z}|$ \\
\hline CG & -0.00003923 & 0.965 & $1.08 \mathrm{E}-08$ & 0.881 \\
Investments & -1.155 & 0 & -1.386 & 0.225 \\
Leverage & -0.214 & 0.115 & -0.836 & 0.085 \\
Liquidity & -0.305 & 0.389 & 3.177 & 0.013 \\
GDP Growth rate & 0.00802 & 0.014 & -0.03 & 0.491 \\
Interest Rate & 0.005 & 0.663 & -0.082 & 0.045 \\
Inflation Rate & 0.022 & 0.005 & 0.008 & 0.776 \\
_Cons & 0.339 & 0.032 & 3.157 & 0.01 \\
& & & & \\
& Wald chi2(7)= & 7.096 & Wald chi2(7)= & 10.263 \\
& Prob $>$ chi2 $=$ & 0.0000 & Prob $>$ chi2 $=$ & 0.0000 \\
& R-sq: within $=$ & 0.343 & R-sq: within $=0.431$ \\
\hline
\end{tabular}

\section{Model 1}

$\mathrm{FP}_{\text {it }}(\mathrm{ROA})=0.339+-0.00003923 \mathrm{CG}_{\mathrm{it}}+-1.155 \mathrm{IN}_{\mathrm{it}-1}+-0.214 \mathrm{LE}_{\mathrm{it}-1}+-0.305$ $\mathrm{LI}_{\mathrm{it}-1}+0.0080215 \mathrm{GDP}_{\mathrm{it}-1}+0.005 \mathrm{INR}_{\mathrm{it}-1}+0.022 \mathrm{IFR}_{\mathrm{it}-1}+\mathrm{c}_{\mathrm{i}}+\dot{\varepsilon}_{\mathrm{it}}$

\section{Model 2}

$\mathrm{FP}_{\text {it }}$ (Tobin's Q) $=3.157+0.0000000108 \mathrm{CG}_{\mathrm{it}}+-1.386 \mathrm{IN}_{\mathrm{it}-1}+-0.836 \mathrm{LE}_{\mathrm{it}-1}+$ $3.177 \mathrm{LI}_{\mathrm{it}-1}+-0.030 \mathrm{GDP}_{\mathrm{it}-1}+-0.082 \mathrm{INR}_{\mathrm{it}-1}+0.008 \mathrm{IFR}_{\mathrm{it}-1}+\mathrm{c}_{\mathrm{i}}+\dot{\varepsilon}_{\mathrm{it}}$

Where;

$\mathrm{CG}=$ Corporate Governance; $\mathrm{IN}=$ Firm Investments; LE = Firm Leverage; LI= Firm Liquidity;

GDP = GDP growth Rate; INR = Interest Rates; IFR= Inflation Rate; $\varepsilon=$ Error Term

\section{Summary and Conclusion}

The study established significant relationship between corporate governance and financial performance of listed agricultural firms in Kenya as measured by both ROA and Tobin's Q. However only occupational expertise, board age, board ownership and board tools had significant effect on financial performance as measured by ROA and; board tenure and board meetings had significant effect on financial performance as measured by Tobin's Q. Remaining corporate governance variables had insignificant effect of financial performance as measured by both ROA and Tobin's Q. The intervening relationship financial characteristics on the relationship between corporate governance and financial performance (investment, investments, leverage and liquidity) were not determined under the four steps of Baron and Kelly (1986) 
original model. The study confirmed the moderating effect of macroeconomic factors (GDP growth rate, interest rate and inflation rate) on the relationship between corporate governance and financial performance of listed agricultural firms in Kenya. The study finally established the significant relationship between corporate governance, financial characteristics and macroeconomic factors on financial performance of listed agricultural firms Kenya.

The study concluded that corporate governance had significance effect on financial performance of listed agricultural firms in Kenya. Good corporate governance structure and activities positively affect financial performance of firms. Financial characteristics (investment, investments, leverage and liquidity) did not intervene in the relationship between corporate governance and financial performance of listed agricultural firms in the original model of Baron and Kelly (1986) where all the four steps must be achieved. However in the reviewed model where we may consider the achievement of some steps, we can conclude that there was some intervention and financial characteristics intervened on the relationship between corporate governance and financial performance (Aluoch et all., 2020). The study further concluded that macroeconomic factors (GDP growth rate, interest rate and inflation rate) had a moderating effect on the relationship between corporate governance and performance of listed agricultural firms in Kenya. This means favorable macroeconomic factors enhance performance of firms in Kenya. The study finally concluded that corporate governance, financial characteristics and macroeconomic factors had significant effect on performance of listed agricultural firms in Kenya. These findings confirm the empirical results of (Zheng, 2021; Oleh Pasko et al,2021; Tleubaye et al., 2020; Roudaki, 2018; Shikanga et al., 2018; Ngwenze \& Kariuki, 2017).

\section{Recommendations}

Based on the findings, the study recommended that listed agricultural firms in Kenya should enhance corporate governance practices to improve financial performance of their firms. Capital Markets Authority of Kenya should review corporate governance principles. Not all principles are effective in improving financial performance. Board occupational expertise, board age, board ownership, board tools, board tenure and board meetings are important corporate governance characteristics in enhancing financial performance of firms.

Directors of listed agricultural firms should diligently improve their financial management practices especially in investments; financing and liquidity to boost financial performance of listed the firms. Macroeconomic variables positively and significantly affect performance of listed agricultural firms; directors therefore should take advantage of favourable macroeconomic environment to increase activities of their firms with the sole aim to improve 
financial performance. Financially Directors of listed agricultural firms take into consideration the joint effect of corporate governance, financial characteristics and macroeconomic factors to achieve higher financial performance of their firms. However there are several factors affecting financial performance of agricultural firms in Kenya such costs of agricultural inputs, general political environment, changes in weather patterns, marketing of agricultural produce, changing prices of global oil and related products given that agricultural production in Kenya is diesel intensive, global pandemics such as Covid-19 among others. There is a need for further research in the relationship between corporate governance and financial performance in Kenya to solve the conflicting results.

\section{References:}

1. Agarwal, V. (2021). What are the pillars of good governance? - The Company Ninja. Retrieved 1 May 2021, from https://thecompany.ninja/what-are-the-pillars-of-good-governance/

2. Agrawal, A. \& Knoeber, C.R. (1996). Firm performance and mechanisms to control agency problems between managers and shareholders. Journal of Financial and Quantitative Analysis 31, 377397.

3. Aluoch, Moses \& Mwangi, Cyrus \& Kaijage, Erasmus \& Ogutu, Martin. (2020). The Relationship between Corporate Governance, Financial Characteristics, Macroeconomic Factors and Performance of Firms Listed at the Nairobi Securities Exchange. European Scientific Journal ESJ. 16. 10.19044/esj.2020.v16n19p169.

4. Aluoch,M.O., Kaijage, S.K., Iraya, C,M, \& Ogutu, M. (2019). Corporate governance, financial characteristics, macroeconomic factors and performance of commercial and services the Nairobi Securities Exchange. International Journal of Business and Social Science, 10(2), 12-26.

5. Anderson, R. W., Bustamante, M. C., Guibaud, S., \& Zervos, M. (2018). Agency, firm growth, and managerial turnover. The Journal of Finance, 73(1), 419-464.

6. Baron, R. M. \& Kenny, D. A. (1986). The moderator-mediator variable distinction in social psychological research: Conceptual, strategic and statistical considerations. Journal of Personality and Social Psychology, 51, 1173-1182.

7. Bhimani, A. (2008). Making corporate governance count: the fusion of ethics and economic rationality. Journal of Management and Governance, 12 (2), 135-147.

8. Brigham, E. B. \& Davis, P. R (2018) Intermediate Financial management, $13^{\text {th }}$ edition, Amazon.co.uk 
9. CMA (2002). Capital Markets Authority, Guidelines on corporate governance practices by public listed companies in Kenya. Gazette Notice No. 3362. Nairobi: Government Printer.

10. CMA (2015)., Capital Markets Authority issues the Code of Corporate Governance Practices for Issuers of Securities to the Public, 2015, for application by both listed and unlisted public companies in Kenya. Gazette Notice No. 1420. Nairobi: Government Printer.

11. Coarse, R. W. (1937). The nature of affirm. Economica, 4(3), 385-405.

12. Daily, C.M., Dalton, D.R. \& Canella, A.A. (2003). Corporate governance: decades of dialogue and data. Academy of Management Review, 28 (3), 371-382.

13. Dioha, C., Mohammed, N.A. \& Okpanachi, J. (2018) Effect of firm characteristics on profitability of listed consumer goods companies in Nigeria, Journal of Accounting, Finance and Auditing Studies, 4(2), 14-31.

14. Egbunike, C. F. \& Okerekeoti, C. U. (2018) Macroeconomic factors, firm characteristics and financial performance A study of selected quoted manufacturing firms in Nigeria, Asian Journal of Accounting Research 3(2)142-168. Emerald Publishing Limited 2443-4175 DOI 10.1108/AJAR-09-2018-00

15. Fama, E. F. \& Jensen, M. C. (1983). Separation of Ownership and Control, Journal of Law and Economics, 26(2), 301-325.

16. Hawley, J.P. \& Williams, A.T. (1996) Corporate governance in the United States: The rise of fiduciary Capitalism". Working Paper, Saint Mary's College of California, School of Economics and Business Administration.

17. Hopt, K.J., (2021). Corporate governance of banks and financial institutions: Economic theory, supervisory practice, evidence and policy. European Business Organisation Law Review 22, 13-37. https://doi.org/10.1007/s40804-020-00201-Z

18. Jensen, M.C. \& Meckling, W. (1976).Theory of the firm: managerial behavior, agency costs, and capital structure. Journal of Financial Economics 3, 305-360.

19. Mwosi, F., Mutesigensi, D. \& Ebong, C. (2018). The role of financial management in supporting firm growth in Uganda, the case of West Nile Region. Journal of Economics \& Management Strategy. 5(1).

20. Ngwenze, M. K., \& Kariuki,M.I. (2017) Effects of corporate governance practices on financial performance of listed agricultural firms in the Nairobi Securities Exchange, Journal of Economics and Finance, 8(3) 106-115.

21. NSE (2017). Nairobi Securities Exchange Hand Book, NSE. 
22. Oleh Pasko, O., Chen, F., \& Wang J. (2021) Does board composition matter? The relationship between board characteristics and financial performance: Evidence from Chinese listed agricultural companies, Research In World Economy 12(1), 177-188. DOI: https://dx.doi.org/10.5430/rwe.v12n1p177

23. Padachi, K. (2006). Trends in working capital management and its impact on firms' performance: an analysis of Mauritian small manufacturing firms, International. Review of Business Research Papers, 2(2), 45-58.

24. Pound, J. (1992). Beyond takeovers: politics comes to corporate control, Harvard Business Review, 70, (2), 83-93.

25. PWC (2019). PriceWaterhouseCoppers Report. Retrieved on $14^{\text {th }}$ Decenber, 2019 on WWW.pwc.com/ke/en/industries/agriculture.htm

26. Richards, V. D., \& Laughlin, E. J. (1980). A cash conversion cycle approach to liquidity analysis, Financial Management, 9(1), 32-38.

27. Roudaki, J. (2018). Corporate governance structure and firm performance in large agriculture companies in New Zealand, Corporate Governance, 18(5), 987-1006.

28. Saseela, B. (2018). Corporate Governance and Firm Performance: Empirical Evidence from Emerging Market, Asian Economic and Financial Review, 8(12), 1415-1421.

29. Sharma, A. K., \& Kumar, S. (2011). Effect of working capital management on firms' profitability: Empirical evidence from India. Global Business Review, 12(1), 159-173.

30. Shikanga, D. M., Mukanzi, C. \& Musiega, D. (2018). Influence of corporate governance on financial performance of agricultural firms listed at the Nairobi Securities Exchange, International Journal of Management and Commerce Innovations, 5(2), 408-420.

31. Tleubaye, A., Bobojonov, I.,Gagalyuk, T., García Meca, E., and Glauben, T (2020) Corporate governance and firm performance within the Russian agri-food sector: does ownership structure matter? International Food and Agribusiness Management Review: 0(0), 1- 20 https://doi.org/10.22434/IFAMR2019.0184

32. Williamson, O. E. (1996). The Mechanisms of Governance. Oxford University Press, Oxford

33. Zheng, D. (2021). Empirical analysis of listed agricultural corporate governance structure and corporate performance, E3S Web of Conferences 235, 02029 (2021). 2020 International Conference on New Energy Technology and Industrial Development (NETID 2020) https://doi.org/10.1051/e3sconf/202123502029 